\title{
APPENDIX II \\ THE SPECIAL SIGNIFICANCE OF THE HAND
}

\section{A. SYNOPSIS}

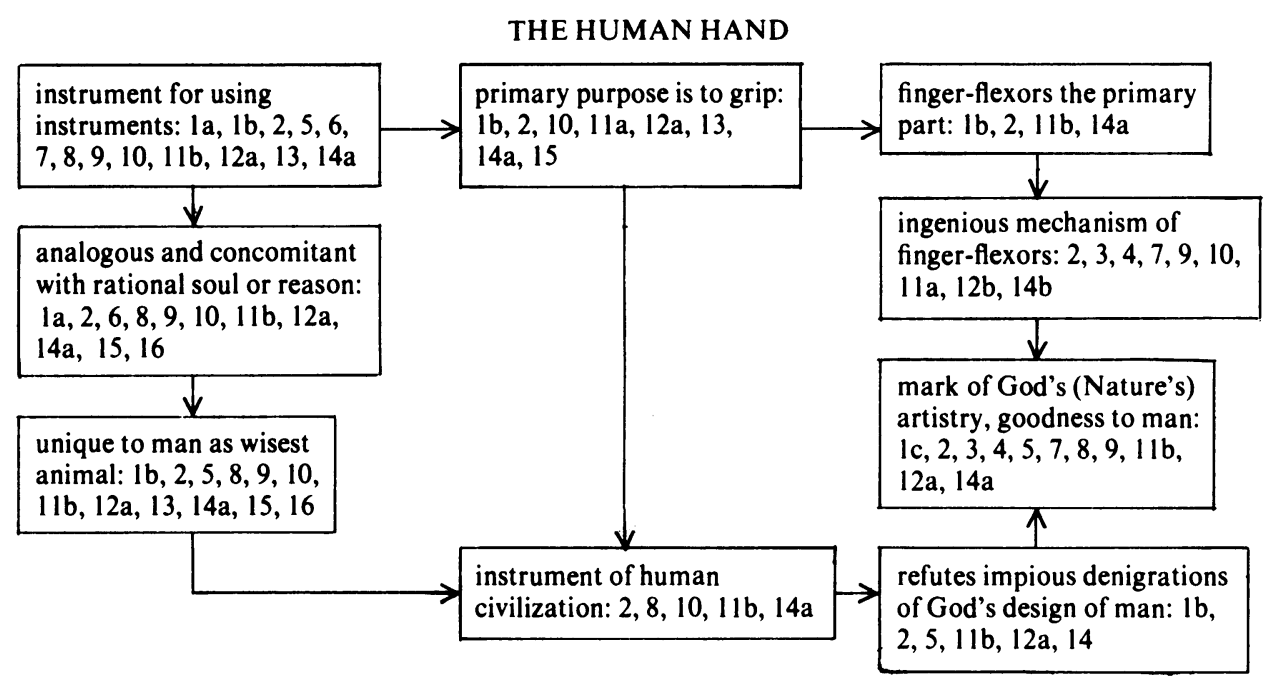

KEY:

1 Aristotle

2 Galen

3 N. Massa

4 A. Vesalius

$5 \mathrm{~J}$. Lygaeus

6 J. C. Scaliger

7 M. R. Columbus

8 V. Coiter

proposed addendum

16.1 N. Tulp

$\begin{array}{ll}\text { B.C. } & 382-322 \\ \text { A.D. } & 129-200 \\ 1536 \\ 1543 \\ 1555 \\ 1557 \\ 1559 \\ 1572\end{array}$

1632

$\begin{array}{ll}9 \text { J. Banester } & 1578 \\ 10 \text { A. Piccolomini } & 1586 \\ 11 \text { A. Laurentius } & 1599 \\ 12 \text { C. Bauhin } & 1605 \\ 13 \text { P. Paaw } & 1615 \\ 14 \text { H. Crooke } & 1615 \\ 15 \text { C. Hofmann } & 1625 \\ 16 \text { J. Riolan } & 1626\end{array}$

1578

1586

1599

1615

1615

1626

\section{B. TEXTS}

1a Aristotle, De anima III. 8 (432 a 1), translated.

... So the soul is as the hand; for the hand is an instrument with respect to instruments, the intellect is a form with respect to forms, and sense-perception a form with respect to things perceived.

\section{1b Aristotle, De partibus animalium IV. 10 (687 a 5- b 24), translated.}

Being erect by nature, man has no need of fore-legs, and so in their stead nature has given him arms and hands. Anaxagoras deduced that it was through having hands that man was the most intelligent animal, but it is a more reasonable view that man received hands because he was the most intelligent. For the hands are an instrument, and nature, like an intelligent person, always distributes instruments according 


\section{The paradox of Rembrandt's 'Anatomy of Dr. Tulp'}

to the recipients' ability to use them. It is more fitting to give a flute to a man who can already play one than to teach the art of flute-playing to a man who has a flute. Nature adds the lesser to the greater and more important, not the other way round. If this is the better way, and nature brings about the best of possible states, then it is not that man is the most intelligent animal because he has hands, but rather that he has hands because he is the most intelligent. For the most intelligent animal would be the one which put the most instruments to good use, and the hand is equivalent not to one instrument but to many. It is, as it were, an instrument for [using] instruments. Therefore nature has given the hand, the most versatile of instruments, to the animal able to take up the most various skills [namely, man].

So those who say that man, far from being well constructed, is the worst constructed of all animals for they say that he is unshod, naked, and without a weapon for self-defence - speak incorrectly. For the other animals have one defence which they cannot exchange for another: they must sleep and do everything without, as it were, taking their sandals off; never lay down their bodily protection, nor change whatever weapon they happen to have. But a man can have many defences and can always change them, and can have any weapon he pleases on any occasion. For the hand is claw and hoof and horn, and spear and sword, and any other weapon or instrument whatever. It will be all these things on account of its ability to seize and hold all of them.

The form of the hand has been well contrived by nature to conform with this role, for it is divided and cleft into many parts. The capacity of united action is permitted by its being divided, but the capacity of divided action would not be permitted if it were a unity. One can use one or two divisions at a time, and in many ways. The joints of the fingers are well constructed for grasping and applying pressure. One of the fingers is placed sideways, and is short and thick, not long like the others; for if it were not so placed, grasping could not occur any more than if the hand did not exist at all. This finger presses upwards from below, the others downwards from above. This must happen if it is to hold things tightly like a strong clamp, the force of the one equalling that of the many ....

\section{1c ps. - Aristotle, Problemata XXX. 5 (955 b 23), translated.}

... God has provided us with two inner instruments with which we use outside instruments, the hand for the body and the intellect for the soul ....

2 Galen, On the use of parts, books I-II passim; book III cc. 1, 10; book XVII c. 1.220

Galen's account of the hand starts from Aristotle's ideas quoted above, but provides vastly more anatomical and philosophical detail, and evinces greater and more overt enthusiasm for the teleological implications of anatomy. ${ }^{221}$

\section{Nicolaus Massa, Liber introductorius anatomiae ... opus sane tam medicis, quam philosophis perutile, ut studiosis lectoribus patebit, Venice, 1536. Fol. 97r:}

Sed quod \& pulcherrimum est uidere, \& non sine Dei optimi benedicti maximis laudibus, est compositio ipsius manus, siue instrumentorum mouentium ipsam manum .... Sed a prima [iunctura digitorum] procedunt chordae perforantes istas chordas, quae figuntur in secunda iunctura per ligamentum cooperiens ipsas chordas, \& per illa foramina transeunt ad tertiam iuncturam digitorum, mouentes ipsas, \& uniuntur cum summis extremitatibus ossium digitorum, \& ita uidebis quod chordae quae mouent primas iuncturas, mouent etiam tertias. Istas tamen perforationes, \& coniunctiones chordarum mirabiles non poteris inspicere, nisi prius incisis tegumentis membraneis . . . 222 ed.).

${ }^{220}$ Text edited by G. Helmreich, 2 vols., Amsterdam, Hakkert, 1968 (repr. of Leipzig, Teubner, 1907-9

${ }^{221}$ Karl Gross, 'Galens teleologische Betrachtung der menschlichen Hand in de usu partium', Sudhoffs Archiv, 1974, 58: 13-24. A picture of Galen lecturing on the uniqueness of the human hand existed in a fifteenth-century Flemish manuscript (published by E. C. van Leersum and W. Martin, Miniaturen der lateinischen Galenos-Handschrift der Kgl. Oeffentl. Bibliothek in Dresden Db 92-93, Leiden, A. W. Sijthoff, 1910, illus. 20, from fol. 59') until it was ruined in the second World War (V. Nutton, 'A forgotten manuscript of Galenus latinus', Studia codicologica, Berlin, Akademie Verlag, 1977, pp. 331-340, p. 334).

222 English translation in L. R. Lind, Studies in pre-Vesalian anatomy, Philadelphia, American Philosophical Society, 1975, pp. 246-247. 


\title{
Appendix II. The special significance of the hand
}

\author{
4 Andreas Vesalius, De humani corporis fabrica, Basle, 1543. Book II, ch. xliii, p. \\ 305:
}

Caeterum his primi musculi tendinibus $[=0$ f $m$. flexor digitorum superficialis] ubi primo digitorum ossi incumbunt, \& priusquam secundum conscenderunt (quanquam secus Galeno uisum fuit) peculiare rarumque ex abundanti id accidit, quod longa sectione diuisi, alium ipsis substratum transmittant tendinem, de quo statim ac praesentis musculi functionem sermoni addidero, sum pertracturus. ... Quemadmodum autem per uniuersam cubiti longitudinem \& bra-[p. 306] chiale secundus musculus [=m. flexor digitorum profundus] primo substernitur, ita quoque primi tendinibus secundi tendines subijciuntur .... Porro ut secundi musculi tendines ad tertium digiti internodium pertingerent, primi iam musculi tendinibus in secundum os necessario insertionem molientibus, operae precium fuit secundi musculi tendines, aut ad tendinum primi musculi latera porrigi, aut quum ipsi recta subijciuntur, incumbentem ipsis tendinem perforari, hacque ratione substratum secundi musculi tendinem transmitti. At ... [the former alternative being impractical] ... reliquum profecto fuit, longa sectione superiorem tendinem, qui primi musculi soboles est, a summo rerum Opifice mirabili industria findi, qua sectione secundi musculi tendo uectus, ad tertij ossis radicem pertingeret. ${ }^{223}$

\section{Joannes Lygaeus, De corporis humani harmonia libri IIII, Paris, 1555. Liber I, excerpt, fol. $4^{\mathrm{r}}$ :}

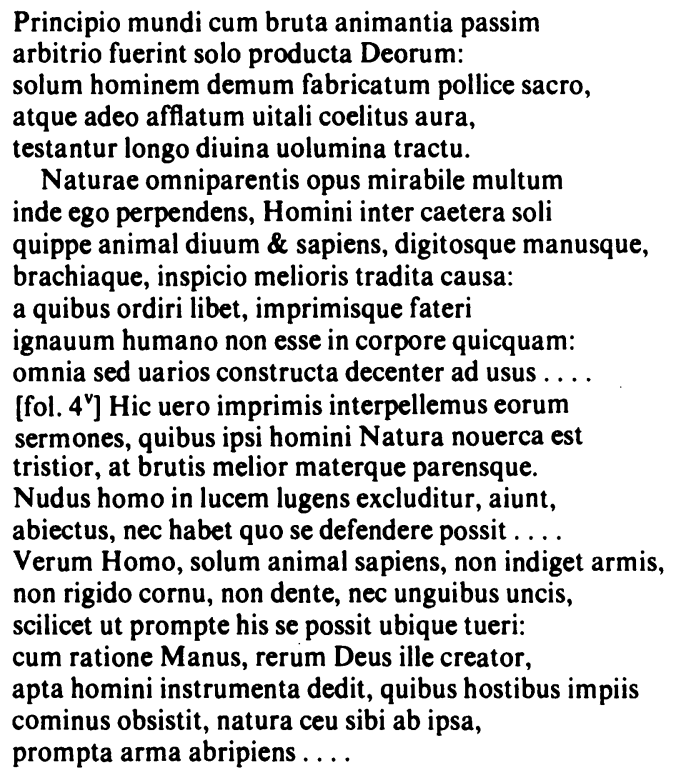

6 J. C. Scaliger, Exotericarum exercitationum liber xv. De subtilitate, ad Hieronymum Cardanum, Paris, 1557. Exercitatio cclvi, 'Ratio. Ingenium. Iudicium. Sermo. Manus', fol. $331^{r}$ :

Manus uero additae: propterea quod intellectus duplex est: ad cognoscendum: \& ad faciendum: unde scientia, et ars. Quas non principiis, sed fine distingui, multis in locis est a nobis demonstratum. Iccirco dicere solitus aliquando fueram: Rationem esse manum intellectus: rationis orationem: orationis manum. Manus enim iussa facit: iussa obediunt rationi: ratio uis intellectus est. Aristoteles in tricesima sectione, de intellectu, scientia, manu, organis, multa apposite, acute, sapienter. Vbi etiam dicit. a Deo

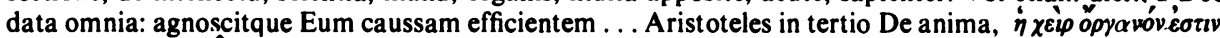

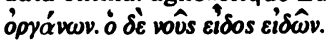

${ }^{223}$ The corresponding passage in the 1555 Basle edition (p. 366) is much less Galenic: the phrase a summo rerum Opifice is omitted. 


\section{The paradox of Rembrandt's 'Anatomy of Dr. Tulp'}

7 M. Realdus Columbus, De re anatomica, Venice, 1559. Lib. V, cap. xxxiii, p. 156:

De musculis summam manum mouentibus. Manus (vt Aristo. \& Gal. inquiunt) organum est organorum: eiusque structura admirabilis est summum artificium prae se ferens. Hanc Deus opt. max. homini concessit vt huius ope omnes artes exercere, seque ab externis iniurijs tueri posset; de qua cum Gal. vir eloquentissimus tam longo processu primo de vsu part. loquutus fuerit, hoc argumentum lubens praeteribo. Ego de summam manum mouentibus musculis postremo loco verba facturus sum hanc vnam ob causam, quod, cum illorum compago miraculi instar esse videatur, in calce de his loquendum existimaui, vt memoriae magis inhaereant, quae in libri calce leguntur. Cum autem Gal. qui \& ipse miram hanc compagem vidit \& animaduertit, statim in initio rem hanc tractauerit, non iniuria quispiam huius mei ordinis causam quaeret. Ne existimetis me in finem hanc materiam reiecisse quod illius oblitus fuerim, vt Gal. contigit libro de vsu part. de musculis [p. 157] femoris, quos obliuione praeterijt; sed vt superius attigi, dedita opera hactenus distuli, vt res pulcherrimas, \& maxime vtiles lectorum mentibus magis haererent ... [p. 158] ... Quartus musculus [=m. flexor digitorum superficialis] exortum habet admirabilem: nerueus etenim acutusque nascitur ab interno humeri tuberculo, carnosus postmodum fit, \& iuxta cubiti radijque longitudinem defertur. Vbi medium cubitum praeterijt, in angustum tendit, terminaturque in quatuor tendines, teretes, nerueos, ac perforatos, qui sub ligamento brachialis deferuntur, sub quo tamen tres primi musculi non deferunter. Terminum habent hi tendines in secundo articulo quatuor digitorum quos flectunt, \& quoniam tendinibus quinti musculi ad tertium articulum quatuor digitorum penetrandum erat, propterea natura hos perforauit, qui neruei sunt, pulchri, pellucidi; resque est \& spectanda \& admiranda. Hoc autem natua sagax effecit, vt digiti ordine quodam sese consequerentur.

Part of this text was translated by Banester, no. 9 below.

\section{Volcher Coiter, Externarum et internarum principalium humani corporis partium} tabulae, Nuremberg, 1572. 'Introductio ... prohoemium sive praefatio', excerpt, fol. AAlr :

... cum summus ille rerum creator mundi fabricam absoluisset, colophonem additurus totumque suum artificium, tanquam in epitomen (vnde philosophi hominem omnium rerum compendium appellant) redacturus, hominem creauit eumque vniuersis dominatorem praefecit ... Vnde quid mirum est, si Deus immensam \& incomprehensibilem potentiam in humano genere condendo collocarit? ... Ideo non vt caeteris animantibus homini certa arma creauit, quibus aut vim, vel mortem inferat, vel illatam propulset, sed manum illi dedit organum ante omnia organa, quibus sibi uaria pro necessitate tum instrumenta, tum arma parare eaque pro temporis occasione \& arripere \& deponere posset . . . .

['Introductio ... cap. octavum', excerpt, fol $\mathbf{A A} 3^{\text {r: }}$ :] In vniuerso corpore contemplanda, est figura, quam Deus homini dedit ad anime infinitas, variasque operationes exprimendas erectam: siquidem cum corpus animae diuinae sit instrumentum, et quasi lucerna, quo vt per lucernam lumen, sic per corpus anime actiones passionesque translucerent, ita componi oportuit, vt omnibus animae actionibus ancillari posset. Hinc factum est quod Deus homini soli inter omnia animalia manus instrumentorum instrumenta concesserit, quibus organa sibi machinatur ad omnes artes exercendas, ad vitam tranquillam, commodam \& beatam ducendam, pertinet \& huc magna distantia beneficio clauicularum, brachiorum a pectore. Quo vero manus tot adeoque varias actiones ederent, necessarium fuit adiungi corporis formam ad eas operationes exequendas, quam accommodatissimam ....

\section{John Banester, The historie of man, sucked from the sappe of the most approued anathomistes, London, 1578.}

[Fol. 31 ${ }^{\mathrm{r}}$ :] ... Thus if we wel perpend the construction, and composition of the partes, and bones of the hand, our senses shall soone conceiue the maner of the action, with no lesse admiration, in beholdyng the handy worke of the incomprehensible Creator: who not one mite, or portion of a part hath sited anywhere, that serueth for no end, or vtilitie to the body: for how fit to apprehend are the handes, and how prompt to moue are the fingers, who is it that knoweth not? whiche made Aristotle call them instruments, or organs, before all organs, or instrumentes: and they are prest, necessary, and exquisite ... [verso] ... Finally this his [i.e. Galen's] saying is also worthy to be noted. As man, of all other creatures, is the most sapient, \& wise, so also hath he handes, the most conuenient instrumentes to a sapient creature: yet not in that he hath hands, therefore he is the wisest, but because he is wisest, therefore he hath handes: for not handes, but reason instructeth man in artes ... . 


\section{Appendix II. The special significance of the hand}

[Fol. 60 ${ }^{\mathrm{v}}$ :] As touchyng the hand so notably of the omnipotent creator created, as that it is most apt, and prompt to all, and euery kynde of art, defence, and safe prouision for the body, so as no member more declareth the vnspeakable power of almighty God in the creatyng of man: because I will nether vse a double labor, nor yet detaine thee with vayne circumstaunce from the summe of the matter, I commit thee to the Hystory of Bones [i.e. fol 31 $1^{\mathrm{r}}$, quoted above], where out of Galen compendiously we haue noted the noble vse and effourmation of this member.

[Fol. 61 ${ }^{\mathrm{r}}$, 'The perforated tendons of the hand':] the end of these tendons is in ye second ioynt of the iii. fingers, which they serue to bow: $\&$ because they were to be penetrated by the tendons of the v. muscle, goyng to the iii, ioynt of the foure fingers as shal be sayd, therefore nature perforated these: which be sinewy, fayre, \& shynning: a thing notable and marueilous to behold. This prudent nature also wrought, to the end that the fingers after a certaine order should follow one an other.

Indebted to Columbus, no. 7 above.

\section{Archangelus Piccolhominus, Anatomicae praelectiones, Rome, 1586.}

[Liber VII, lectio vii, 'de musculis apprehensoriis, idest, manum mouentibus ..., conclusion, p. 326:] His paucis \& breuiter \& dilucide exposita sit mirifica ipsius manus fabrica. Ex quibus, illud manus encomium a maioribus praeditum, verissimum esse cognoscitur, cum promulgarunt, manum esse organum organorum.

[Liber VIII, lectio x, 'de ossibus digitorum', conclusion, p. 377:] Quis est totius manus vsus? Apprehensio; data enim in hunc finem est manus, \& vt apprehendat \& vt sit, scribente Aristotele, organum organorum, hoc est, organum \& instrumentum ipsius mentis in efficiendis instrumentis omnibus ex aliqua materia constantibus, ad aliquam hominis commoditatem \& vtilitatem spectantibus. Itaque manus erit mentis instrumentum, quum quibus animantibus caducis mens insit, in eisdem insit manus; \& contra. Quemadmodum enim cerebrum est mentis sensitiuae instrumentum, quo vtitur in opera perficienda, quaecumque mens iusserit. Quam mirificum sit manus artificium \& opificium, qui id exploratum habere cupit, legat Galeni primos de vsu partium libros, in quibus manuum nobilitatem \& sublimitatem ita celebrat, vt omnes legentes \& meditantes, in summam admirationem trahat.

\section{Andreas Laurentius (Dulaurens), Historia anatomica humani corporis, Frankfurt a. M., 1599.}

\section{Lib. V, cap. xxviii, 'De musculis digitorum quatuor', p. 140:}

Manus organi omnium nobilissimi, mirabilem structuram suo loco describemus: ea tantum quae ad historiam musculorum spectant, explicare consilium est. Manus propria actio est apprehensio, vnde

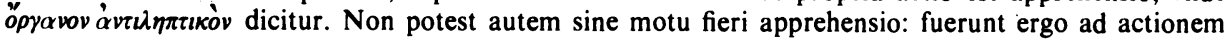
manus musculi necessarii .... Digitos ergo quatuor flectunt tres musculi; palmaris, sublimis, \& profundus. Palmaris ... Sublimis ab interna brachij apophysi enatus, priusquam ad carpum perueniat, quatuor tendines tanquam habenas emittit .... Profundus priori substratus, ab eodem exortus tuberculo, in totidem neruosos tendines scinditur ... [p. 141] Vt autem profundo huic musculo ad tertiam articulationem pateret aditus, natura mirabili artificio sublimis tendines quatuor perforauit.

11 Lib. XII, cap. iii, 'De manuum praestantia', p. 437 - cap. iv, 'De vsu, figura \& structura extremae manus', p. 438: see translation by H. Crooke, no. 14a of this appendix, pp. 62-63 below.

\section{Caspar Bauhin, Theatrum anatomicum, Frankfurt a. M., 1605.}

\section{2a Lib. IV, cap. i, 'De manu', p. 1031:}

Cum Deus ter Opt. terque Max. hominem solum inter creata animalia nudum \& inerme creasset (cuius nomine Epicurus, Plinius, alijque ethnici Deum imperfectionis \& iniustitiae ethnice accusant) ad sui tamen imaginem clementer formasset, ne brutis animalibus inferior foret, rationem \& manum ei dedit, quae cȩteris animantibus denegauit. Rationem cerebro indidit, quae omnium artium officina \& ars ante 


\section{The paradox of Rembrandt's 'Anatomy of Dr. Tulp'}

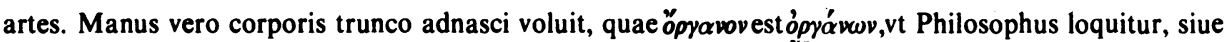
instrumentum ante omnia instrumenta, data autem homini tanquam animalium sapientissimo, cum organum sit animalium sapientissimo conueniens, $\&$ id pro corporis nuditate, ne inermis esset, sed manu sibi varia tum instrumenta, tum arma pro necessitate \& sui defensione pararet, \& pro temporis occasione \& arripere \& deponere posset, sicque foret instrumentum ad omnes artes necessarium, paci non minus quam bello idoneum. Cuius actio est apprehensio, quare Galenoöpyavov ávtul

[P. 1032] Verum cum manus actio sit apprehensio, apprehensio autem absque motu fieri non possit, musculis tanquam motus voluntarij instrumentis opus habuit, quare primaria manus pars, quae primo \& per se actionem edit, musculus est ....

Reprinted unchanged in the Frankfurt 1621 edition, pp. 548-549.

\section{2b Lib. IV, cap. xv, 'De musculis digitos quatuor flectentibus', p. 1094:}

Flectentium [primus (=m. flexor digitorum superficialis)] ... per vinae et radij anteriorem partem, mediam delatus ... in partes quatuor carnosas diuiditur, quae singulae in tendines exquisite rotundos, nerueos \& pellucidos cessant: qui ... delati ad digitorum quatuor os secundum iuxta articuli partem mediam longa sectione diuisi, quo subsequentis \& subiecti tendines, qui ad tertium articulum ferri debuere, transmittantur \& quo facilius moueant \& apprehendant, latiores redditi, paulo post diuisionem in digitorum quatuor ossa secunda inseruntur: quae sane res admiranda spectatuque digna, quod a natura prudenti factum, quo digiti ordine quodam sese consequantur \& digitorum recta [p. 1095] inflexio efficiatur.

Derived largely from Columbus (no. 7 above); translated by Crooke (no. 14b below); and reprinted unchanged in the Frankfurt 1621 edition, p. 578.

\section{Petrus Pavius (Paaw), Primitiae anatomicae de humani corporis ossibus, Leiden} 1615, p. 156:

Manus ... manibus capere \& arripere obvia solemus. Hunc usum commode praestare uti manus posset, explicatos discretosque fecit digitos natura, quo etiam minutissima quaeque capere, fingere, forma[p. 157]reque possimus. Quod respiciens Anaxagoras organorum organum manum vocare solebat, dicereque vel solo manuum respectu hominem mereri prudentis solertisque animalis nomen. Nihil etenim pene ingenii solertia aut acumen excogitare potest, manibus quod non aptare perficereque homo queat. Inde videntur Scriptores sacri Summi Dei admiranda expressuri opera, manuum uti voce. Manus tuae fecerunt \& formaverunt me, inquit Psalmista. Idem, Dextera Domini excelsa est, dextera Domini fecit fortitudinem \&c.

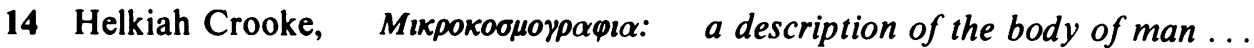
collected and translated out of all the best authors of anatomy, especially out of Gasper Bauhinus and Andreas Laurentius, London, 1615.

14a The following is translated from Laurentius (no. 11b above). Book IX, chap. iii [=Laurentius lib. XII, cap. iii], 'Of the excellency of the hands', p. 729:

Man, who is the crowne and pride of Nature that bold and confident worke-mistrisse, him I say, God on his birth day did cast out vpon the dust of the earth, naked, vnarmed, and weltring in his bloud, to enioy or rather to deplore an inheritance of sorrow and misery. Yet notwithstanding because he is sent into the world to be a combetant and not a sluggard. He hath armed him with two wondrous weapons, which He hath denied to all other liuing creatures, reason and the hand. His reason is the storehouse of all arts and sciences, the first groundworke and foundation of whatsoeuer the immortall soule is naturally capable or apprehensiue of; an arte it is, as before all arts, so hath it all arts for his subiect or matter whereabout it is occupied. The hand is an instrument, but as it is the first instrument so it is the framer, yea and employer of all other instruments. For not being framed for any one particular vse it was capeable of all: so as it may iustly be compared to the soule, which as the Philosopher saith is, though not in deed yet in power and ability all things. By the helpe of the hand lawes are written, temples built for the seruice of the 


\section{Appendix II. The special significance of the hand}

Maker, ships, houses, instruments, and all kind of weapons are formed. I list not to stand vpon the nice skill of painting, drawing, caruing and such like right noble artes, whereby many of the ancients haue made their names honorable vnto vs, yea and eternized them to the worlds end. By our hands we promise, we call, we dismisse, we threaten, we intreate, we abhorre, we feare, yea and by our hands we can aske a question. By the helpe of the hand although a man be borne vnarmed, yet is he able to safegard himselfe from all other creatures: and all those creatures which come strong and armed at point into the world, how fierce soeuer they be, how able to abide the violence of heauen it selfe, yet are they not safe from the hands of men. For doth not the industry of mens hands preuaile against the hornes of the bull, the teeth of the lyon and the paw of the beare, yea whatsoeuer is comprehended vnder the cope of heauen, by the skill of the hand is brought vnder our subiection and made tributary vnto us.

[P. 730] And therefore Anaxagoras as Plutarch reporteth, marking diligently the curious fabrick of the hands, the postures of the fingers, as they moue either together or apart, the mighty strength, the cleane nimblenesse and the soft delicacy thereof, ascribed vnto them the cause and originall of mans wisedome. How much wiser was Galen who in those melodious hymnes which he wrote to the praise of his Creator, I meane his bookes of the Vse of Parts discoursing very curiously concerning this curious instrument concludeth, that man is not therefore the wisest of all creatures because he hath hands, but because hee is the wisest of all creatures, therfore Nature furnished him with this excellent instrument. It was not the hand that taught men arts but reason, yet the seruant and minister of this reason and wisedome is the hand: they are the vicars or substitutes and suffraganes of the speech, the interpreters of the secret language of our silent conceits, signifying to all men in a few letters as it were by hieroglyphicks what the very thoughts of our heartes are....

[Book IX, chap. iv [=Laurentius lib. XII, cap. iv], 'Of the vse, figure and structure of the hand ...':] The true office of the hand is to apprehend or to holde, and his proper action is apprehension ... from

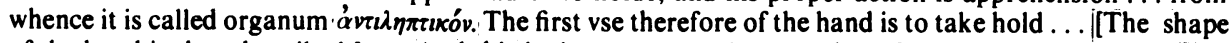
of the hand is then described.] ... And this is the manner and proportion of the figure. For the structure if it be diligently attended, it will imprint in vs an admiration of the wonderful skill [P. 731] and workemanship of Nature and it is on this manner. Because the hand was the most noble and perfect organ or instrument of the body: God the Creator moulded it vp of diuers particles, all which for our better vnderstanding we will referre vnto foure kindes. The first kinde is of those which originally and by themselues doe performe an action .... The first and principall part of the hand is a muscle, because there is no apprehension without motion; now wee know that a muscle is the immediate organ of voluntary motion....

14b The following is translated from Bauhin (no. 12b above). Book X, chap. xxx, 'Of the muscles which bend and extend the forefingers', p. 787:

The first bender $[m$. flexor digitorum superficialis $]$. . . passeth thorough the middle and anterior part of the ell and the wand [ulna and radius] . . . and ... is ... diuided into four fleshy parts, all which do determine into tendons, exquisitely neruous and transparant ... and at the second bone of the forefingers nere the middest of the ioynt are diuided with a long section or slit through which the tendons of the next muscle to be described (which lyeth under them [m. flexor digitorum profundus]) which were to reach vnto the third ioynt are transmitted. There they become broader that they might mooue more easily and apprehend or take holde the better, and a little after the diuision or section they are inserted into the second bones of the foure fingers. And truly this progresse and insertion of these muscles is an admirable and strange worke of Nature: for they are so seuered, that the fingers in their motion might orderly follow one another, and each of them alone bend inward.

\section{Caspar Hofmann, Commentarii in Galeni de usu partium corporis humani lib.} XVII ... Opus, non medicis tantum sed et philosophis, nec minus philologis paratum, Frankfurt a.M., 1625. 'Argumentum libri primi et secundi ...', p. 5:

Iam, quia anima hominis sapientissima est, corpusque habet per quod sapientiam suam prodere potest: omnis ratio videtur suadere, agendum esse primo loco de illa parte, per quam homo est homo. Ea vero est manus ... serviunt hae partes uni actioni, apprehensioni, quam manus praestat ... Apprehensio igitur est actio illa, ad quam usus omnium heic dicendarum partium spectat . ... Manus ergo nostra, per quid est manus? per quid apprehendit? per conformationem. Licet autem conformatio haec pertineat ad totam manum, de qua agimus: praecipue tamen pertinet ad summam manum. 


\section{The paradox of Rembrandt's 'Anatomy of Dr. Tulp'}

['Cap. ii: iii. iv.', p. 7:] Homo, animalium sapientissimus, manus habet animali sapienti convenientes. Quare subito etiam laudat Aristotelem .... Propter manus homo solus est . . animal sapiens, \& propter sapientiam ... divinum .... Iam ergo in promtu est ratio, cur Gal. ordiatur a manu, quia agit principaliter de homine: utique ab illa hominis parte incipere illum aequum est, qua praecipue est homo. Illa vero est manus, ut 4 quoque Ex. Anat. I ait.

16 Johannes Riolanus, Anthropographia et osteologia, Paris, 1626. Lib. I, cap. i. p. 20:

... Nec satis laudatum esset corpus humanum, nisi quorundam calumnias \& opprobria in naturam inique iacta, \& temere effutita repellerem, quibus diuinum opificium imperfectum esse cauillantur ... [p. 21] ... Has omnes calumnias, \& deliramenta refellere facillimum est. Homo, inquit Aristoteles, sicut corpus armis nudum, sic animam artibus destitutam habet, sed pro corporis nuditate manus, pro animae imperitia rationem accepit: quorum vsu \& ministerio corpus quidem omni genere armorum munire potest, animam autem omnibus artibus exornare. Nam, vt prudenter ait Philo Iudaeus, pro omnibus brutorum donis ratio homini data est, qua sibi factam iniuriam vlciscatur. Rationi tamen manus additae, quae praesto essent ad iussa capessenda \& exequenda, vt intellectus duplex est, ad cognoscendum \& ad faciendum, vnde scientia \& ars; ita dicere solitus erat Scaliger . . . [cf. no. 6, p. 59 above].

\section{proposed addendum}

16.1 The action of Nicolaes Tulp in Rembrandt's painting in the Mauritshuis, the Hague. See pp. 22-23 above.

\section{aftermath}

The history of these ideas of the human hand after 1632 need not be traced in detail here. Among the works which would be examined in a thorough study of the subject are John Ray's The wisdom of God manifested in the works of the Creation, 3rd edition seen, London, 1701, pp. 286-290; A. G. Plaz, De corporis humani machina divinae sapientiae teste, Leipzig, 1725, pp. 24-25; and William Paley's Natural theology; or evidences of the existence and attributes of the Deity, 12th edition seen, London, 1809, pp. 143-144, where we read of the intersections of the flexor-tendons of the fingers, "There is nothing, I believe, in a silk or cotton mill, in the belts, or straps, or ropes, by which motion is communicated from one part of the machine to another, that is more artificial, or more evidently so, than this perforation". J. F. Hartlaub, in his Diss. phil. de homine Dei teste, Jena, 1733, p. 4, refers to a Demonstratio Dei ex manu humana by "Donatus", which I have not identified. Pictures which might have a bearing on this theme include Richard Greenbury's double-portrait of Sir Charles Scarburgh and Edward Arris, c. 1650 (London, Worshipful Co. of Barbers); J. J. Haid's mezzotint portrait of Lorenz Heister, after a painting by M. W. Fröling; and Joseph Wright of Derby's Hermit (Derby, Art Gallery). More recent studies include Charles Bell's Bridgewater treatise The hand: its mechanism and vital endowments as evincing design, 2 nd edition seen, London, 1833, the subject of which had been specified by the 8th Earl of Bridgewater in his will dated 25 February 1825; G. M. Humphry's lectures The human foot and the human hand, Cambridge, 1861, pp. 156-158; Frederic Wood Jones's classic The principles of anatomy as seen in the hand, London, Baillière, Tindall \& Cox, 1920 and 1941; and successive editions of Gray's Anatomy not excluding the current (36th) British edition (Edinburgh, 


\section{Appendix II. The special significance of the hand}

Churchill Livingstone, 1980, p. 591), where we still find this distant echo of Anaxagoras, Aristotle, and Galen:

Though the repertoire [of the hand] is essentially limited, the scope of the basic movements and the nicety of control with which they can be exercised, are unrivalled perquisites of man. This manual skill, guided by discriminative vision, and directed by a highly imaginative and inquisitive mentality into a seemingly endless range of activities, has enabled mankind to master much of the natural environment, and to create around himself a culture of art, science and technology. The ever-increasing complexity of this artificial environment has carried us far beyond any other form of life of which we are aware. 